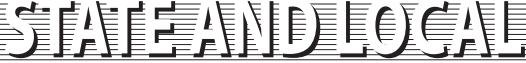

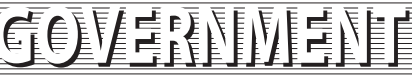

\section{EVALUATION OF THE EFFECTIVENESS OF THE MODERN SYSTEM OF PUBLIC ADMINISTRATION IN SYRIA AND THE POSSIBILITY OF INTRODUCING CHANGE MANAGEMENT}

\author{
Naeim David Hurmuz \\ The Russian Trade and Economic Development Council's Special Representative \\ for Interaction with the Syrian Arab Republic. PhD student, School of Public \\ Administration, National Research University, Higher School of Economics (HSE) \\ Address: 20 Myasnitskaya Str., 101000 Moscow, Russian Federation. \\ Email: naamwel@yahoo.com, naeim.hurmuz@mail.ru
}

\section{Abstract}

The article analyzes the current situation in the state administration of Syria on the basis of statistical data. It is shown that the changes in the structures of the Syrian state power observed over the past few years have demonstrated the inability to change the highly decentralized, inefficient and non-transparent system, or to create an integral, balanced, reliable and effective public administration. The main shortcomings of the Syrian state now lie in its inability to provide an effective impact on the distribution of limited resources and the disparity in the distribution policy of limited resources to the prevailing public perception of justice. It is substantiated that the existing problems stemming from the poor effectiveness of the Syrian public administration authorities, taking into account resource constraints, population reduction, inflation and unemployment growth, and the growing gaps between rich and poor and rural and urban residents can be solved by introducing the technology of management of change "Point localized impact", which seems to be an effective tool for increasing the efficiency of public authorities, the establishment of public services, and the provision of conditions for economic growth and social well-being. The article argues that the change management can ensure the development of territorial communities and the state as a whole, since the subjects of management themselves can exercise control over the areas that require improvement and development.

Keywords: efficiency; effectiveness; public administration; decentralization of public administration; local administration bodies.

Citation: Hurmuz, N.D. (2018). Evaluation of the Effectiveness of the Modern System of Public Administration in Syria and the Possibility of Introducing Change Management. Public Administration Issue, Special Issue II (electronic edition), pp. 107-118 (in English); DOI: 10.17323/1999-5431-2018-0-6-107-118 


\section{Introduction}

The development of a civilized democratic society requires the creation of a state system capable of ensuring social harmony and a financial and economic balance. Modern development of public administration in Syria is marked by complexity and contradiction, as it occurs in the context of military conflict and an unstable social and economic situation, inconsistency of real demands and opportunities of society to realities of life, and negative geopolitical tendencies (Hajjar et al., 2016).

One of the main problems of public administration in Syria is associated with the low level of effectiveness of public administration, weighed down by the loss of a single managerial space, and the fragmentation of socio-economic processes. Such phenomena, as we know, hamper economic growth, and increase the budget deficit, jeopardizing the financing of state programs of socio-economic development (Finley et al., 2001). All this requires the formation of an effective mechanism of public administration corresponding to the realities, goals and objectives of Syrian society.

The need for reforming public administration is due to new socio-economic, political and socio-cultural challenges that affect the functioning of the state. The best practices of other states, also often faced (with few exceptions, not to the same extent as Syria) with resource constraints and with extraordinary geopolitical circumstances, show that management of changes in such cases is good technology that allows for the efficient use of limited resources. It is the management of changes that can become a reference point for the development of public administration in Syria; the improvement of such management is an objective need, and requires responsibility and the active participation of the society.

\section{Formulation of the problem and literature overview}

Today in Syria, there are reformist movements towards decentralization. This is the choice of the priority way of development, there is a gradual replacement of separately functioning in Syria public administration, local government and civil society by a synthetic public management discourse (Seifan, 2011). In this regard, it is important to consider the category of "public administration" in terms of its relationship with the mechanisms for the exercise of state power and the adoption of managerial decisions. A major contribution to the study of the problem of public administration in this direction was made by M. Kotler (Kotler, 1969), D. Keeling (Keeling, 1972), M. Mescon, M. Albert, F. Khedouri (Mescon et al, 1988), and C. Hood (Hood, 1997), as well as modern researchers G.V. Atamanchuk (Atamanchuk, 2015), G.A. Borshchevsky (Borshchevsky, 2018), D.A. Limareva, V.N. Nekrasov (Limareva, Nekrasov, 2012), and L.I. Voronina, S.N. Kostina, and A.V. Tomiltsev (Voronina et al., 2017).

In paying tribute to their scientific heritage, it should be noted that research on this subject subsequently evolved considerably. Today, the public administration system covers many subsystems. Its sphere of interests includes political, economic, social, administrative and legal, humanitarian systems. The sphere of its formation and development is influenced both by internal (unbalanced socio-political system 
of the state) and external (geopolitical challenges, world trends of social transformations, etc.) factors (Public Administration, 2015). The semantic content of the definition of the category "public administration" is realized through the prism of understanding its role in the life of society, the state and each individual (Khalikov, 2008). Today, the aspect of interaction between the state and civil society in public administration is very important, unlike the traditional vision of public administration as the organizing and regulatory impact of the state on society.

In particular, research into the functioning of public administration is particularly important for countries such as Syria. At present, the focus of public administration research has changed in view of the observed phenomenon of instability of country development. The former formulation of the problem of the functioning of public administration as consisting of subsystems (public administration, local government, management with the participation of civil society - participation governance) has been replaced by a more acute formulation: how these subsystems can interact in conditions of resource constraints, adverse geopolitical circumstances, devastation and hostilities.

An important place in modern studies is given to the problem of efficiency and various options for its solution. Thus, according to M. Milakovich and G. Gordon, democracy and good governance are mutually supportive (Milakovich \& Gordon, 2012). On the other hand, F. Fukuyama believes that states should be disaggregated into their component parts, both in terms of functional and regional characteristics, and in terms of management level, and that simultaneous measurement and capacity and autonomy are needed to assess all these components (Fukuyama, 1989), i.e., the quality of governance is highly determined by the interaction of abilities and autonomy that alone cannot be adequately used to measure the quality of government activity.

Researchers identify three key functions of public administration: 1) maintaining safety; 2) effective provision of basic public services; and 3) ensuring political participation and accountability (Kornhauser, 1968; Lindquist, 2006). At the same time, many researchers believe that namely the change management, as it is connected with the separation of power and responsibility in the political, fiscal and administrative spheres between the center and the periphery, serves as a tool for transforming managerial architecture (Put \& Bouckaert, 2013). Attention is focused on the internal complexity of this process, which combines a set of goals aimed at achieving greater efficiency, equity, better governance, supporting political stability and reducing poverty.

In this connection, it is important to understand that the ability of local authorities and their leaders to manage change is determined by certain factors, among them:

1) The extent to which local governments are able to effectively manage new powers and resources;

2) How the local government system takes into account the dynamics of political competition, the ability of local leaders to mobilize resources to achieve change, and the need for modernization of public administration;

3) How the management of changes affects democratic governance (Obolonsky, 2011). 
That implementation of change management will allow not only to exercise power authority on the basis of law, but also to focus further on the effectiveness of public administration, ensuring maximum satisfaction of public needs on the basis of minimum costs (Pollitt, 2004). With regard to the use of the change management at the local level, the priority in this direction is the implementation of the reform of local self-government in Syria, which should aim at replacing the previously formed system of centralized power for decentralization.

Change management allows for increasing the efficiency of the system of institutions through which power is exercised in the country, public policies are implemented and public services are provided. The following management criteria for changes are distinguished: proper legislation; legality; participation; transparency of the decision-making process; access to the information; effective state administration; qualified personnel efficiency of financial and budgetary management; and responsibility and supervision (Maxwell et al., 2016; McCullough, 2015). The basic characteristics of change management according to the materials of the United Nations Economic and Social Commission for Asia and the Pacific (ESCAP) include participation, consensus orientation, accountability, speed of response, non-discrimination (inclusiveness) and the rule of law, and is primarily related to methods and technologies (UN Public Administration Glossary, 2016). We believe that such characteristics are currently lacking within the system of public administration in Syria.

Summarizing various aspects of increasing the effectiveness of public administration, it can be argued that the management of change, deregulation, decentralization and policy flexibility requires a higher level of competence and ethical standards for individual managers than those that currently exist in developing countries, including Syria. The main problem is the fundamental difference between countries that have already implemented a radical transformation of the political system, and other countries that are only introducing public administration within the old political system that are not suitable for this, because they often lack the political will and public support for the implementation reforms.

\section{Methods of Research: The Contemporary Condition of the Control System in Syria}

The statistics show that the globalization shifts and the military conflict in Syria together resulted in a structural transformation of power systems and mechanisms in the Syrian state. In Syria, there are pathologies of the traditional administrativebureaucratic concept of public administration. Pressure of external and internal factors forces the government to search for alternative directions of administrative activity, adapted to a qualitatively new state of the socio-economic system of the state. The military conflict has caused great damage to the civilian population in Syria (World Bank, 2017). Life expectancy has declined by more than 20 years (from 79.5 years in 2011 to 55.7 in 2016) (CIA, 2017). All this has led to a serious increase in the gap between the poor and the rich in the country (Figure 1). As can be seen from the figures in Figure 1, over the six year period the gap in the national average has increased more than eight times. This problem is aggravated for the population of rural areas, where the gap is three points higher than in urban areas 
and higher than the national average. An important problem is the annual increase in unemployment, which for the youth exceeds 70\% (Figure 2).

\section{Poverty gap in Syria, \%}

Figure 1

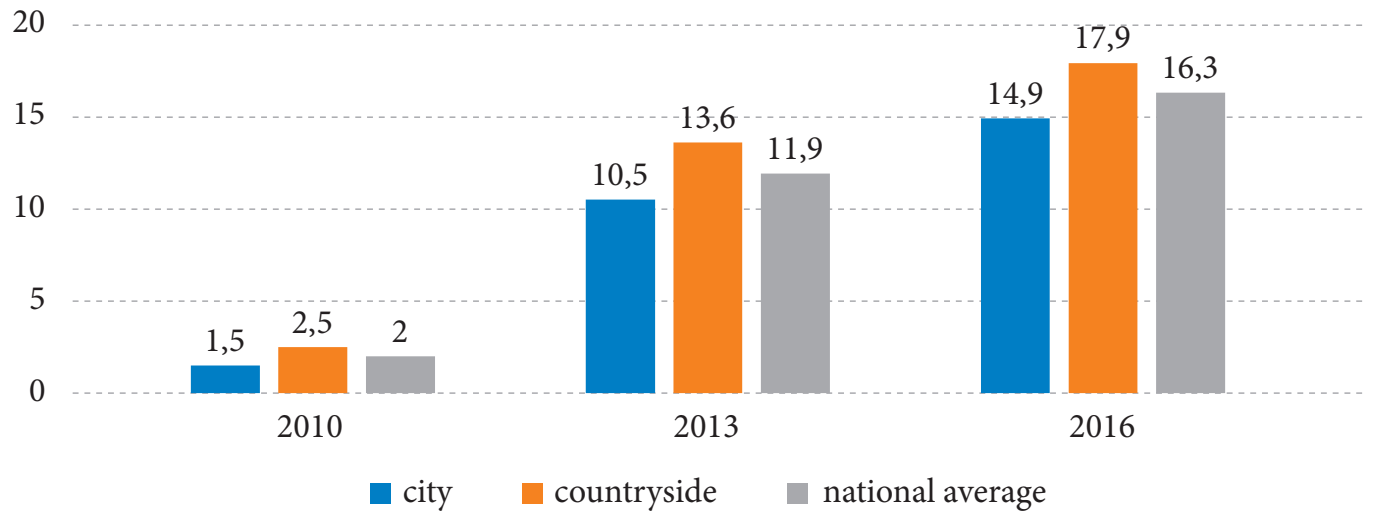

Source: Author's publication according to data (EPDC, 2017, CLS, 2017)

\section{Unemployment rate in Syria, \%}

Figure 2

100

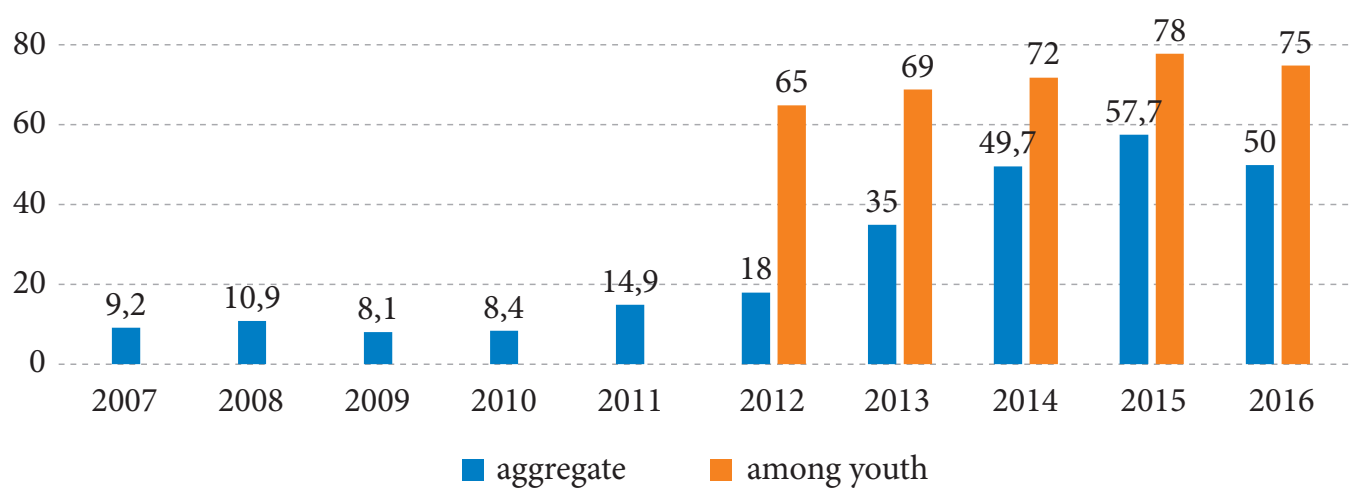

Source: Author's publication according to data (EPDC, 2017, CLS, 2017)

The data presented in Figure 2 demonstrate that, since 2011, the unemployment rate increased annually until 2015, when its level reached a maximum of $57.7 \%(+49.3 \%)$. In the following year, unemployment fell by $7.7 \%$. But the value of this indicator at the level of $50 \%$ means that half of the able-bodied population is unemployed, which aggravates the already difficult situation in the country.

The situation is even more negative, since more than half of the country's population has been granted refugee status in recent years and moved inside or outside the country (UNESCO, 2018), which led to a decline in the population (Figure 3). In addition, there is a high level of inflation of the national currency (Figure 4). 
Figure 3

\section{The population of Syria, million people}

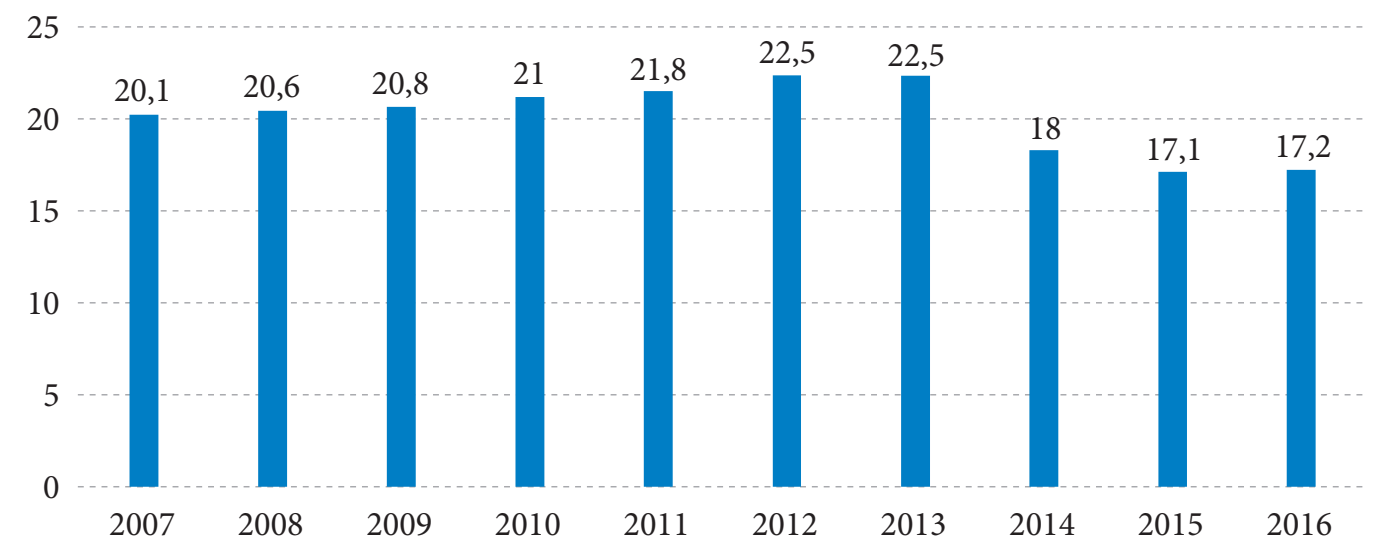

Source: Author's publication according to data (EPDC, 2017, CLS, 2017)

\section{Dynamics of inflation in Syria, \%}

Figure 4

100

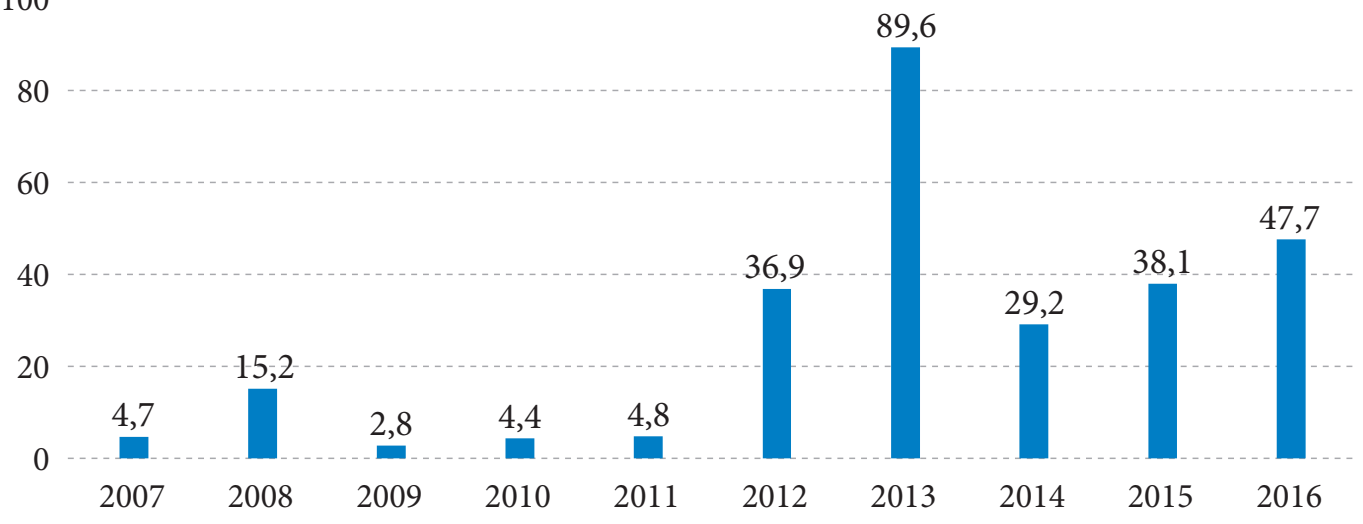

Source: Author's publication according to data (EPDC, 2017, CLS, 2017)

Analysis of the statistical data presented in Figure 4 shows that the fairly stable rate of the Syrian currency during 2009-2011 was replaced by an annual increase in inflation, the maximum level of which was fixed in 2013 at $89.6 \%$. Thus, we can conclude that today in Syria there is a very tense social situation, accompanied by a decline in economic indicators, the degradation of human capital, and the military-political conflict.

Nevertheless, under these conditions, administrative reform in Syria continues on the old "patterns" of building "socialism with an Arab face", which was a combination of principles of socio-economic justice and a rigid state dictatorship. This reform began at the beginning of B. Assad's rule (Al Bish, 2012). At present, it is not taken into account that in Syria, soon after the death of Hafez Assad in 2000 , serious structural problems began. Of course, there have been some achieve- 
ments along this path, but it is still necessary to recognize their slow pace, the inconsistency of the process of improving the legal, institutional, organizational, procedural and technological foundations of the state mechanism, especially if we take into account the world trends of changes in public administration. In the process of reforms, there was a reduction in government spending, subsidies and social guarantees, as well as the growth of the private sector by reducing the standard of living of the population. All of this led to the classic consequences of neoliberal reforms: a significant increase in social inequality, urban-rural inequality, an increase in the number of Syrians living below the poverty line, and rising unemployment. Many rural areas were left without a profitable part of the budget (Seifan, 2011). That is why in 2010-2011, unrest began, which then developed into a military conflict (Simons, 2013).

Let us now turn to the analysis of the modern system of public administration in Syria. Today, the entire territory of Syria is divided into several categories: areas in which the Assad government operates, areas subordinate to the opposition, and areas under the control of terrorists. The specificity of public administration in the Syrian Arab Republic is that the key subject that determines the strategy of the economic and political state is its head (Sapunov, 2015).

Within the territorial boundaries of Syria, there are administrative units, including governorates, cities, municipalities, districts and sub-districts. At the same time, during the conflict, administrative structures, including local administrative councils (LAC), Sharia-based institutions and traditional institutions, including related, religious and ethnic (Center for Humanitarian Dialogue, 2014), began to be created. That is, in Syria there is also local self-government, although many call it a purely formal institution. Local administrative councils base their legitimacy on Legislative Decree No. 107 on decentralization, adopted in Damascus in August 2011 as part of a package of legislative reforms.

According to some researchers, the Decree became an integral part of the Syrian public administration and could become the basis for a potential basis of governance in post-conflict Syria (LACU, 2016). The Syrian constitution proposed by Russia in January at the ceasefire negotiations in Astana contains provisions that clearly indicate the type of decentralized system enshrined in Decree No. 107. Nevertheless, despite popularity, it remains unclear how Decree 107 will be implemented on a national scale or how this will affect the socio-economic development of the country. An expanded system of local councils can allow Syrians across the country to interact more actively with the government, but it can also become another level of bureaucratic control. Much depends on whether local councils have sufficient authority to respond effectively to local needs and problems.

All public expenditures are carried out from a single state budget under the authority of the Ministry of Finance. Local authorities receive all the funds from the central government, and any excess income should be returned to the state treasury. In the state there is a high level of corruption accompanied by decision-making in the sphere of public administration under the influence of the confessional factor, with full control of the chiefs, who are often in kinship relations. 
It can be seen that the low efficiency of implementing managerial decisions in the field of public administration in Syria is related to the following factors:

1. High centralization of public administration and, at the same time, the existence of areas with other management systems.

2. The president of the country has great powers, with which he does not allow the development of territorial communities.

3. The inability of the state to fully control the counterparty's reaction to its actions. Intervention of the state in the economy can cause negative side effects (externalities).

4. Imperfection of the political process. Under the influence of voters, groups of special interests, political manipulation, etc. Public bodies most often use inadequate methods of regulation and thereby conduct ineffective policies.

5. Limited control over the state apparatus. The peculiarities of the position and behavior of the bureaucracy can increase the inefficiency of the functioning of the economy, in particular, leading to excessive growth of the administrative apparatus and an unjustified increase in budget expenditures.

The Syrian state is characterized by situations where both market failures and imperfections of state intervention occur simultaneously (the weakening of the impact of certain deficiencies often only strengthens the influence of others). When making economic decisions, one must compare the consequences of the influence of market and state deficiencies in order to determine the optimal form and boundaries of state regulation. In addition, there is a situation of limited information and the almost complete absence of national (conducted in Syria itself) analysts. The use of any tools should be based on an analysis of the possible consequences of decisions. Where there is a lack of objective data, which makes it impossible to predict the results with sufficient certainty, one should generally refrain from excessive government intervention in the economy.

\section{Conclusions and Discussion of the Results}

The conducted study of the current system of responsibility in Syria allows us to draw the following conclusions. Despite the fact that public authorities in cooperation with other actors are involved in the provision of public services, in many cases it does not meet the needs of the population. These processes face a number of key problems. One of the main problems is the lack of financial resources to provide services, repair and expand infrastructure, or manage and pay staff. During the military conflict, many actors began to participate and compete for the provision of public services in various areas. The parameters of the intervention of the public administration authorities vary in different parts of the country in accordance with various control zones (government regime, opposition, Kurdish districts). The system of responsibility in different areas of Syria and at different levels of government is also different, so there is no single approach to this problem. An important problem is the lack of a mechanism for prompt and extensive feedback. The limitations of public administration include institutional weaknesses in the organization of these processes, including low efficiency and productivity, lack of experience and a clear strategy. 
In this connection, the question naturally arises: can new management practices be applied on changes in countries with a traditionally rigid bureaucratic administration and an underdeveloped market economy? Despite the existing warnings, we believe that it is necessary to take into account the international experience of carrying out administrative reforms. One can agree that there is no universal transformational model, but the general trend must always be taken into account. In this context, the lesson that Syria needs to learn from the experience of other countries is important. This lesson is that the adaptation of the public administration to new realities implies the need for broad participation of citizens, primarily in the process of defining goals and objectives of the reform, as well as close partnership between the state and non-state sectors, since it is impossible to get high results when reforming The government does not comply with the norms and values of society. We believe that in this situation, serious efforts are needed to synchronize and harmonize the reform processes of both state power and society.

The existing challenges put before the Syrian state are the need to implement a management on changes, ensure the effective functioning of the entire system of state authorities and local government bodies, and broad involvement of various stakeholders in the development and implementation of state policy, in particular civil society institutions. The ultimate goal of introducing change management is to ensure "proper management", that is, to make public management as accessible, transparent and effective as possible. Thus, it can be concluded that management issues on changes are key in the context of reform and initiatives in the field of public administration.

Not only technical and analytical innovations should be included in the notion of change management, but also reforming public administration in such a way as to ensure the needs of the state as an institution on the one hand, as well as the interests of citizens and enterprises, on the other. In this context, change management as a form of public administration is one of the tools for the development of society; it ensures the increase of efficiency, openness and transparency of the activities of public authorities and local self-government, the effectiveness of which is confirmed by the positive experience of the leaders' countries.

We believe that only the technology of change management, which includes the harmonization of state administration proper, local self-government and management of participation by civil society, will make it possible to neutralize excessively centralized management processes in a fragmented country suffering from a socioeconomic catastrophe. The transfer of resources "on site", their use by local communities with the participation of civil society, and assistance from the state without dictating what should be done, is the only opportunity for Syria to revive. It would be necessary to include the formula of public administration as a management tool for changes in the new Constitution of Syria.

Summarizing the above, it can be concluded that, at the moment, an effective public administration system has not been established in Syria, which requires the need for greater efficiency in the activities of state institutions, including transparency, participation, accountability, and the force of law. Previously developed international principles and standards have not yet found comprehensive imple- 
mentation in the acts of administrative law of Syria, which is due primarily to the lack of a unified system in the Syrian legal system.

At the same time, it should be noted that in modern conditions, public evaluation of the effectiveness of public administration assumes great importance, reflecting the degree of satisfaction of the interests and needs of individual citizens and society as a whole. The state, acting as the main social institution, should react to the expectations of society for improving public administration by creating a structure of public administration that is most focused on the realization of the needs of citizens. In such transformations, public authorities should use mechanisms and procedures that require continuous evaluation, monitoring of performance, and direct citizen participation, while applying various technical solutions. Such processes just characterize the transition of the state to a qualitatively new level, a new way of interacting with citizens. That is why the management of changes, which is a component of the concept of effective public administration, is now important.

\section{Conclusion}

Summarizing the above, it can be concluded that, at the present stage of the development of the Syrian state, it is necessary to raise the level of effectiveness of public administration by increasing the effectiveness of management decisions taken and determining the responsibility of public authorities for the results of decisions taken and implemented, which determines the need to use change management in activities of state administration.

In particular, the tasks of the management on changes in the sphere of public administration in Syria can be a synergistic combination of the concepts of rational bureaucracy, the new state administration, the main factors of which are: changing the functions and structure of executive bodies in order to eliminate duplication of their powers; reform of the system of budget expenditures and incomes; reform of the system of state regulation; concentration and decentralization of power; reorganization of state control; deregulation and simplification of management procedures; organization of free access to information reflecting the results of government activities; implementation of the mechanism of statepublic consultations on the development of political decisions; formation and development of knowledge management in the system of state power; ensuring an effective system of incentives for administrative reform at the level of territorial authorities; the creation of an information exchange infrastructure and support for the implementation of administrative reform at all levels of government; application of modern information technologies; reforming the principles and standards of the civil service; and implementation of the principle of accountability and government control of public organizations. 


\section{REFERENCES}

1. Al Bish, O. (2012). Russia and Syria: Relationships, Proven By Time. Dialogue of civilizations: East-West. Globalization and Multiculturalism: Russia in the Modern World. Materials XII scientific conference of young scientists. Moscow: RUDN, pp. 241-248(in Russian).

2. Atamanchuk, G.V. (2014; 2015). Ideino-nravstvennyipotentsial v preduprezhdeniikrizisovipovysheniieffektivnostigosudarstvennogoupravleniia [Ideological and Moral Potential in Preventing Crises and Improving the Effectiveness of Public Administration]. Right and Management. The XXI century, vol. 30, no 1 pp. 25-33; vol. 34, no 1, pp. 41-46 (in Russian).

3. Borschevsky, G.A. (2018). Reform of the Bureaucracy through the Eyes of Political Leaders. State Administration of the Russian Federation: Challenges and Prospects. Moscow: Moscow State University, pp. 579-589(in Russian).

4. Center for Humanitarian Dialogue (2014). Local Administration Structure in Opposition-held Areas in Syria. Geneva, Center for Humanitarian Dialogue.

5. CIA (2017). The World Factbook - Syria Country Profile. Available at: https://www.cia.gov/ library/publications/the-world-factbook/geos/sy.html (accessed: May 20, 2018).

6. Finley, O., Vaughan, G. \& Radcliffe, S. (2001). A call for papers: histories of accounting and public policy. Journal of Accounting and Public Policy, vol. 20, no 2, pp. 91-96.

7. Fukuyama, F. (1989). The End of History and the Last Man.

8. Hajjar, B., von Burg, C., Hilal, L., Santschi, M., Gharibah, M. \& Sharbaji, M. (2017). Perceptions of Governance - The Experience of Local Administrative Councils in Opposition-held Syria. Swiss Peace Report. Available at: http://www.swisspeace.ch/fileadmin/user_upload/ pdf/Mediation/WOTRO_Report_The_Experience_of_Local_Administrative_Councils_in_ Oppositionheld_Syria.pdf (accessed: 04 October, 2018).

9. Hood, C. (1991). A Public Management for All Seasons? Public Administration, vol. 69, no 1, pp. 3-19.

10. Keeling, D. (1972). Management in Government. London: Allen \& Unwin.

11. Khalikov, M.I. (2008). System of State and Municipal Management. Moscow: Flint.

12. Kornhauser, W. (1968). The Politics of Mass Society. London: Routledge and Paol.

13. Kotler, M. (1969). Neighborhood Government: The Local Foundations of Political Life. New York: Bobbs Merrill.

14. LACU (2016). LACU and Conflict Dynamics International Options for Decentralization in Syria. LACU Workshop Report.

15. Limareva, D.A. \&Nekrasov, V.N. (2012). Contradictions of Modern Public Administration: Monograph. Rostov-na-D: URIU RANEPA under the President of the Russian Federation (in Russian).

16. Lindquist, E. (2006). A Critical Moment: Capturing and Conveying the Evolution of the Canadian Public Service. Ottawa: Canadian School of Public Service.

17. Maxwell et al. (2016). Complexities of Service Delivery and State-Building. Secure Livelihoods Research Consortium Briefing, Paper 21. 
18. McCullough, A. (2015). The Legitimacy of States and Armed Non-State Actors. Topic Guide. Birmingham, University of Birmingham.

19. Mescon, M.H., Albert, M. \& Khedouri, F. (1988). Management. New York: Harper \& Row.

20. Milakovich, M. (2016). Public Administration in America. M. Milakovich, G. Gordon. $11^{\text {th }}$ edition. Wadsworth Publishing.

21. Obolonsky, A.V. (2011). The Crisis of the Bureaucratic State. Reforms of the Civil Service: International Experience and Russian Realities. Moscow: The Liberal Mission Foundation (in Russian).

22. Pollitt, C. (2004). Public Management Reform: A Comparative Analysis. Oxford: University Press.

23. Public Administration (2015). Public Administration in the Context of Globalization: Mechanisms, Regularities, Perspectives: Proceedings of the International Scientific and Practical Conference, May 28-30, 2015. Ed. V.V. Nekrasova. Rostov-na-D.: Publishing house of the URI RANEPA (in Russian).

24. Put, V.\&Bouckaert, G. (2013). Managing Performance and Auditing Performance. The Ashgate Research Companion to New Public Management. Burlington: Ashgate Publishing Company.

25. Sapunov, V. (2015). Neo-Liberal Economic Reforms of the 21 $1^{\text {st }}$ Century as the Cause of the Civil War in Syria. Available at: http://4pera.ru/news/analytics/neoliberalnye_ekonomicheskie_ reformy_xxi_veka_kak_prichina_grazhdanskoy_voyny_v_sirii/ (accessed: May 20, 2018).

26. Seifan, S. (2011). The Road to Economic Reform in Syria. Published by the University of St Andrews Center for Syrian Studies School of International Relations Fife, Scotland UK.

27. Simons, G.J. (2013). Military Intervention and Syria: Forward to Outright Aggression? Space and Time, vol. 2, no 12, pp. 31-46.

28. The CLS (2017). Official website of the Central Bureau of Statistics of Syria. Available at: http:// www.cbssyr.sy/Introduction.htm (accessed: May 20, 2018).

29. UN Public Administration Glossary (2016). UN Public Administration program. Available at: http://www.unpan.org/DPADM/ProductsServices/Glossary/tabid/1395/language/en-US/ Default.aspx (accessed: May 20, 2018).

30. UNESCO (2018). Country Profiles: Syrian Arab Republic. UNESCO Institute for Statistics. Available at: http://uis.unesco.org/ (accessed: May 20, 2018).

31. Voronina, L.I. (2017). Functions and Services in the System of State and Municipal Management: Monograph. Ekaterinburg: Publishing house Ural. University (in Russian).

32. World Bank (2017). Data and Development indicators. Available at: http://data.worldbank. org/indicator (accessed: May 20, 2018). 